\title{
Thermoanaerobacter tengcongensis sp. nov., a novel anaerobic, saccharolytic, thermophilic bacterium isolated from a hot spring in Tengcong, China
}

Institute of Microbiology, Academia Sinica, Beijing 100080, China

\author{
Yanfen Xue, Yi Xu, Ying Liu, Yanhe Ma and Peijin Zhou
} Author for correspondence: Yanhe Ma. Tel: +86010 6255 3628. Fax: +8601062560912.
e-mail: mayh@sun.im.ac.cn

\begin{abstract}
A new, extremely thermophilic bacterium, designated strain $\mathrm{MB4}^{\top}$, was isolated from a Chinese hot spring. The new isolate was an obligately anaerobic, rod-shaped, Gram-negative, saccharolytic bacterium. Spore formation was not observed. Growth occurred at temperatures between 50 and $80^{\circ} \mathrm{C}$, with an optimum of around $75{ }^{\circ} \mathrm{C}$; at pH values between 5.5 and 9.0, with an optimum of 7.0-7.5; and at salinities between 0 and $2.5 \% \mathrm{NaCl}$, with an optimum of around $0.2 \% \mathrm{NaCl}$. The organism utilized glucose, galactose, maltose, cellobiose, mannose, fructose, lactose, mannitol and starch. Acetate was the main end product from glucose fermentation. Thiosulfate and sulfur were reduced to hydrogen sulfide. Sulfate, sulfite and nitrate were not reduced. Growth was inhibited by hydrogen. The $G+C$ content of the DNA was $33 \mathrm{~mol} \%$. Phylogenetic analyses based on the $16 \mathrm{~S}$ rDNA sequence indicated that the isolate was a new member of the genus Thermoanaerobacter and formed a monophyletic unit within the Thermoanaerobacter cluster. Based on its phenotypic and phylogenetic characteristics, the isolate was proposed as a new species, Thermoanaerobacter tengcongensis. The type strain is MB4 ${ }^{\top}$ ( $=$ Chinese Collection of Microorganisms AS $\left.1.2430^{\top}=J C M 11007^{\top}\right)$.
\end{abstract}

Keywords: Thermoanaerobacter, thermophiles, saccharolytic bacterium

\section{INTRODUCTION}

The biotechnological potential and evolutionary significance of thermophiles has led to intensive studies on the biology of anaerobic, saccharolytic thermophiles, which are found in all types of thermal habitats (Brock, 1986; Wiegel et al., 1985; Kristjansson \& Stetter, 1992). Most of these isolates have been characterized and described as members of the genera Thermoanaerobacter, Thermoanaerobacterium and Clostridium (Weigel \& Ljungdahl, 1981; Lee et al., 1993).

Anaerobic thermophiles have been isolated from widely distributed hot springs, for example Thermoanaerobacter brockii (Zeikus et al., 1979) and Thermoanaerobacterium xylanolyticum (Lee et al., 1993) from the hot springs of the Yellowstone National Park, Fervidobacterium nodosum from a thermal spring in

The GenBank accession number for the 16S rRNA gene sequence of strain MB4 ${ }^{\top}$ is AF209708.
New Zealand (Patel et al., 1985) and Thermoanaerobacter italicus from a thermal spa in Italy (Kozianowski et al., 1997). To date, there are few reports on anaerobic thermophiles from Chinese hot springs. During investigations on the microbial diversity of Chinese hot springs, we isolated a new thermophilic bacterium designated strain $\mathrm{MB}^{\mathrm{T}}$, which is classified as a new member of the genus Thermoanaerobacter on the basis of phenotypic and phylogenetic analyses. The name Thermoanaerobacter tengcongensis is proposed.

\section{METHODS}

Sample source. Mixed sediment and water samples were taken from a hot spring in Tengcong, located in Yunnan Province, China. At the site of sampling, the temperature was $86^{\circ} \mathrm{C}$, the $\mathrm{pH}$ value was $7 \cdot 0$ and the $\mathrm{NaCl}$ concentration was $0 \cdot 25 \%(\mathrm{w} / \mathrm{v})$.

Enrichment, isolation and cultivation. The modified MB medium (Fardeau et al., 1997) used for the experimental studies contained (per litre distilled water): $\mathrm{NH}_{4} \mathrm{Cl}, 1.0 \mathrm{~g}$; 
$\mathrm{K}_{2} \mathrm{HPO}_{4} \cdot 3 \mathrm{H}_{2} \mathrm{O}, 0 \cdot 3 \mathrm{~g} ; \mathrm{KH}_{2} \mathrm{PO}_{4}, 0 \cdot 3 \mathrm{~g} ; \mathrm{MgCl}_{2} .6 \mathrm{H}_{2} \mathrm{O}, 0 \cdot 5 \mathrm{~g}$; $\mathrm{NaCl}, 2.0 \mathrm{~g} ; \mathrm{KCl}, 0.2 \mathrm{~g} ; \mathrm{CaCl}_{2}, 0.05 \mathrm{~g}$; trace element solution (Balch et al., 1979), $9 \mathrm{ml}$; cysteine. $\mathrm{HCl}, 0.5 \mathrm{~g}$; yeast extract, $1.0 \mathrm{~g}$; tryptone, $2.0 \mathrm{~g}$; starch, $10 \mathrm{~g}$. The medium was boiled under a stream of oxygen-free $\mathrm{N}_{2}$ gas and cooled to about $80^{\circ} \mathrm{C}$. The $\mathrm{pH}$ of the medium was adjusted to $7 \cdot 5$ with $2 \mathrm{M}$ $\mathrm{NaOH}$, then dispensed into Hungate tubes under oxygenfree $\mathrm{N}_{2}$ gas and autoclaved. Prior to inoculation, thiosulfate was injected from sterile stock solutions to obtain a final concentration of $20 \mathrm{mM}$. All incubations were at $75^{\circ} \mathrm{C}$ unless otherwise noted. The $\mathrm{pH}$ value of the medium did not change more than $0.3 \mathrm{pH}$ units at the different temperatures used.

Enrichment was performed anaerobically in $30 \mathrm{ml}$ glass bottles containing $20 \mathrm{ml}$ modified MB medium. Media were inoculated with $2 \mathrm{ml}$ samples and incubated at $80^{\circ} \mathrm{C}$ without agitation for $3 \mathrm{~d}$. Purification was repeated at $65^{\circ} \mathrm{C}$ in modified MB agar deeps $(2 \%, \mathrm{w} / \mathrm{v}$, agar) and Hungate roll tubes (Hungate, 1969) with $3 \%$ agar.

Characterization. Gram reaction was determined by staining (Doetsch, 1981) and by the KOH lysis method (Buck, 1982). Cell morphology and motility were examined by phasecontrast microscopy and electron microscopy during exponential-growth phase in modified MB medium. Amino acid composition of the cell wall was determined by the method of Schleifer (1985).

$\mathrm{pH}$, temperature and $\mathrm{NaCl}$ concentration ranges for growth were determined in modified $\mathrm{MB}$ medium. For the $\mathrm{pH}$ range, the medium was adjusted to $\mathrm{pH}$ values between 5 and 10 with $\mathrm{HCl}$ or $\mathrm{NaOH}$ and $10 \mathrm{ml} \mathrm{CO}_{2}$ was injected into the headspace of the tube by syringe prior to autoclaving. The $\mathrm{pH}$ value of the medium was adjusted by injecting $\mathrm{NaHCO}_{3}$ or $\mathrm{Na}_{2} \mathrm{CO}_{3}$ from $10 \%(\mathrm{w} / \mathrm{v})$ sterile anaerobic stock solutions and measured at $75^{\circ} \mathrm{C}$ with a model $\phi 71 \mathrm{pH}$ meter (Beckman) equipped with a temperature probe and calibrated at $75^{\circ} \mathrm{C}$ prior to inoculation. For $\mathrm{NaCl}$ requirements, different amounts of $\mathrm{NaCl}$ were weighed directly into the tubes prior to dispensing the medium.

Substrate utilization was tested in modified MB medium containing $1 \mathrm{~g}$ tryptone $1^{-1}$ and $1 \mathrm{~g}$ yeast extract $1^{-1}$ and without starch. Substrates in sterile stock solutions were added to the medium at a final concentration of $20 \mathrm{mM}$ except for yeast extract $(0 \cdot 2 \%, \mathrm{w} / \mathrm{v})$, tryptone $(0 \cdot 2 \%, \mathrm{w} / \mathrm{v})$ and Casamino acids $(0 \cdot 2 \%, \mathrm{w} / \mathrm{v})$. The controls were grown without any substrate addition.

To test for electron acceptors, compounds prepared as sterile stock solution were added to the modified MB medium at a final concentration of $20 \mathrm{mM}$ except for oxygen (atmospheric concentration) and elemental sulfur $\left(1 \mathrm{~g} \mathrm{l}^{-1}\right)$. The medium was prereduced with cysteine in the experiments with sulfate, sulfite, thiosulfate and elemental sulfur. No reducing agents were present in medium with oxygen. Both reduced and reducing-agent-free media were used in the experiment with nitrate. The utilization of the electron acceptors was monitored by measuring growth and sulfide production. The effect of a hydrogen atmosphere on growth of strain $\mathrm{MB}^{\mathrm{T}}$ was tested using modified $\mathrm{MB}$ medium containing $0.5 \%$ glucose with and without thiosulfate or sulfur.

To test antibiotic susceptibility, ampicillin, chloromycetin, penicillin, polymyxin B, streptomycin sulfate or tetracycline. $\mathrm{HCl}$ from filter-sterilized stock solutions were each added at a final concentration of $100 \mu \mathrm{g} \mathrm{ml}^{-1}$ to sterile medium.
Analytical techniques. All experiments were performed in duplicate. The strain was subcultured at least once under the same experimental conditions prior to determination of growth rates. Bacterial growth was monitored by optical density at $600 \mathrm{~nm}$.

For negative staining, cells were suspended in $0.9 \% \mathrm{NaCl}$ solutions and allowed to attach to a grid, followed by washing with $2 \%(\mathrm{w} / \mathrm{v})$ ammonium acetate and negatively staining with $2 \%(\mathrm{w} / \mathrm{v})$ ammonium molybdate. For platinum shadowing, cells were applied to a carbon-coated grid, washed once with distilled water and shadowed with platinum-carbon at an angle of $18^{\circ}$. For thin sectioning, cells were fixed with $0.5 \%(\mathrm{w} / \mathrm{v})$ glutaraldehyde and $1 \%$ (w/v) $\mathrm{OsO}_{4}$ at $4{ }^{\circ} \mathrm{C}$, embedded in Epon epoxy resin and stained with $1 \%(\mathrm{w} / \mathrm{v})$ uranyl acetate and lead citrate. Photomicrographs were taken with a Hitachi transmission electron microscope.

Short-chain fatty acids and alcohols were analysed by GC on a Shimadzu GC-9A gas chromatograph with $5 \%$ FAPP on a Chromosorb-G glass column and an FID detector. $\mathrm{H}_{2}$ and $\mathrm{CO}_{2}$ were analysed by $\mathrm{GC}$ on a Shimadzu GC-7AG gas chromatograph with a Porapak Q glass column and a TCD detector. Glucose was determined by HPLC (Waters) with a Sugar-pak-1 column $(300 \times 6.5 \mathrm{~mm}$; Waters $)$ and a Waters 410 RI detector. Hydrogen sulfide formation was detected by the addition of $\mathrm{FeSO}_{4}$ to the culture, a black precipitate indicating the presence of sulfide.

Sporulation test. Cultures grown in media with or without glucose or starch were examined for the presence of spores at different growth phases. The heat resistance of cells was determined in modified MB medium. After $2 \mathrm{~d}$ incubation at $75^{\circ} \mathrm{C}$, duplicate cultures were heated at $100{ }^{\circ} \mathrm{C}$ for 20 or $30 \mathrm{~min}$ and subcultured into fresh medium $(20 \%, \mathrm{v} / \mathrm{v}$, inoculum). The resulting cultures were incubated at $75^{\circ} \mathrm{C}$ for $3 \mathrm{~d}$.

DNA and 16S rDNA studies. Genomic DNA was prepared by the method of Marmur (1961), and the purity was checked spectrophotometrically. The $\mathrm{G}+\mathrm{C}$ content of the DNA was determined by the thermal denaturation method according to Marmur \& Doty (1962) using Escherichia coli DNA $(51 \mathrm{~mol} \% \mathrm{G}+\mathrm{C})$ as standard.

16S rDNA was amplified from strain $\mathrm{MB}^{\mathrm{T}}$ genomic DNA by PCR with Taq DNA polymerase (Promega) and primers 5'-AGAGTTTGATCCTGGCTCAG-3' and 5'-AAGGAGGTGATCCAGCCGCA-3', which correspond to positions 8-27 and $1541-1525$ in the $16 \mathrm{~S}$ rDNA (E. coli numbering; Brosius et al., 1978). The PCR products were cloned into vector $p G E M-T$ using the pGEM-T vector system I kit according to the manufacturer's instructions (Promega). The sequences were determined using the dideoxy sequencing method (Sanger et al., 1977) supplied in kit form on an ABI 373S DNA sequencer (Applied Biosystems).

Phylogenetic analysis of $16 \mathrm{~S}$ rDNA sequences. The $16 \mathrm{~S}$ rDNA sequence from strain $\mathrm{MB} 4^{\mathrm{T}}$ was compared against all deposited nucleotide sequences in the GenBank database by using the Basic BLAST 2.0 option (Altschul et al., 1997), implemented as a sequence similarity search tool at the home page of the National Center of Biotechnology Information (http://www.ncbi.nlm.nih.gov). Close relatives were retrieved and aligned with each other using CLUSTAL W version 1.8 (Thompson et al., 1994). The phylogenetic tree was drawn by using the neighbour-joining method (Saitou \& Nei, 1987) with the Kimura two-parameter calculation model in TREECON for Windows version 1.2 (Van de Peer \& 
De Wachter, 1994). Tree topologies were evaluated by bootstrap analysis based on 100 resamplings of the neighbour-joining dataset.

The accession numbers of the reference strains used in the sequence comparison were as follows: Thermoanaerobacter acetoethylicus ATCC 33265 ${ }^{\mathrm{T}}$, L09163; Thermoanaerobacter brockii subsp. brockii ATCC 33075 , L09165; Thermoanaerobacter ethanolicus ATCC 31550 ${ }^{\mathrm{T}}$, L09162; Thermoanaerobacter kivui DSM 2030 ${ }^{\mathrm{T}}$, L09160; Thermoanaerobacter brockii subsp. finnii DSM 3389 ${ }^{\mathrm{T}}$, L09166; Thermoanaerobacter brockii subsp. lactiethylicus DSM 9801 ${ }^{\mathrm{T}}$, U14330; Thermoanaerobacter thermocopriae IAM $13577^{\mathrm{T}}$, L09167; Thermoanaerobacter thermohydrosulfuricus DSM 567 ${ }^{\mathrm{T}}$, L09161; Thermoanaerobacter wiegelii DSM $10319^{\mathrm{T}}$, X92513; Thermoanaerobacter siderophilus DSM 12299", AF120479; Thermoanaerobacter italicus DSM 9252 ${ }^{\mathrm{T}}$, AJ250846; Thermoanaerobacter mathranii DSM $11426^{\mathrm{T}}$, Y11279; Thermoanaerobacterium saccharolyticum DSM 7060 ${ }^{\mathrm{T}}$, L09169; Thermoanaerobacterium xylanolyticum DSM 7097 ${ }^{\mathrm{T}}$, L09172; Thermoanaerobacterium thermosulfurigenes ATCC $33743^{\mathrm{T}}$, L09171.

\section{RESULTS}

\section{Enrichment and isolation}

For enrichment and isolation of anaerobic, saccharolytic thermophiles, modified MB medium was inoculated with $10 \%(\mathrm{w} / \mathrm{v})$ of samples. Prior to inoculation,
$\mathrm{Na}_{2} \mathrm{~S} .9 \mathrm{H}_{2} \mathrm{O}$ and $\mathrm{NaHCO}_{3}$ in sterile stock solution were injected to obtain final concentrations of $0.05 \%$ $(\mathrm{w} / \mathrm{v})$ and $0 \cdot 2 \%(\mathrm{w} / \mathrm{v})$, respectively. Turbidity caused by cell growth was observed after incubation at $80^{\circ} \mathrm{C}$ for $3 \mathrm{~d}$. Microscopic examination revealed bacterial populations composed of nonsporulating rods. After several successive transfers, the positive enrichment cultures were serially diluted and purified in agar deeps and roll tubes. Single colonies developed in the agar deeps and roll tubes after incubation at $65^{\circ} \mathrm{C}$ for $2 \mathrm{~d}$, and were then picked and subcultured in liquid medium. The process was repeated five times, after which the culture was considered to be pure. A pure culture was designated strain $\mathrm{MB} 4^{\mathrm{T}}$.

\section{Colony and cellular characteristics}

Colonies of strain $\mathrm{MB} 4^{\mathrm{T}}$ in agar deeps or roll tubes were round, creamy white and had diameters of about $1-2 \mathrm{~mm}$ after $2 \mathrm{~d}$. The cells of strain MB4 ${ }^{\mathrm{T}}$ were rods, $1-10 \mu \mathrm{m}$ in length with a diameter of $0 \cdot 5-0 \cdot 6 \mu \mathrm{m}$, and occurred singly or in pairs or chains. The cells were Gram-negative by staining and by the $\mathrm{KOH}$ lysis test. Electron microscopy of ultrathin sections revealed a cell wall with a thin, intensely stained inner layer and a less densely stained outer layer (Fig. 1). No endospores were observed by phase-contrast microscopy under the conditions used and no cells survived in the heat
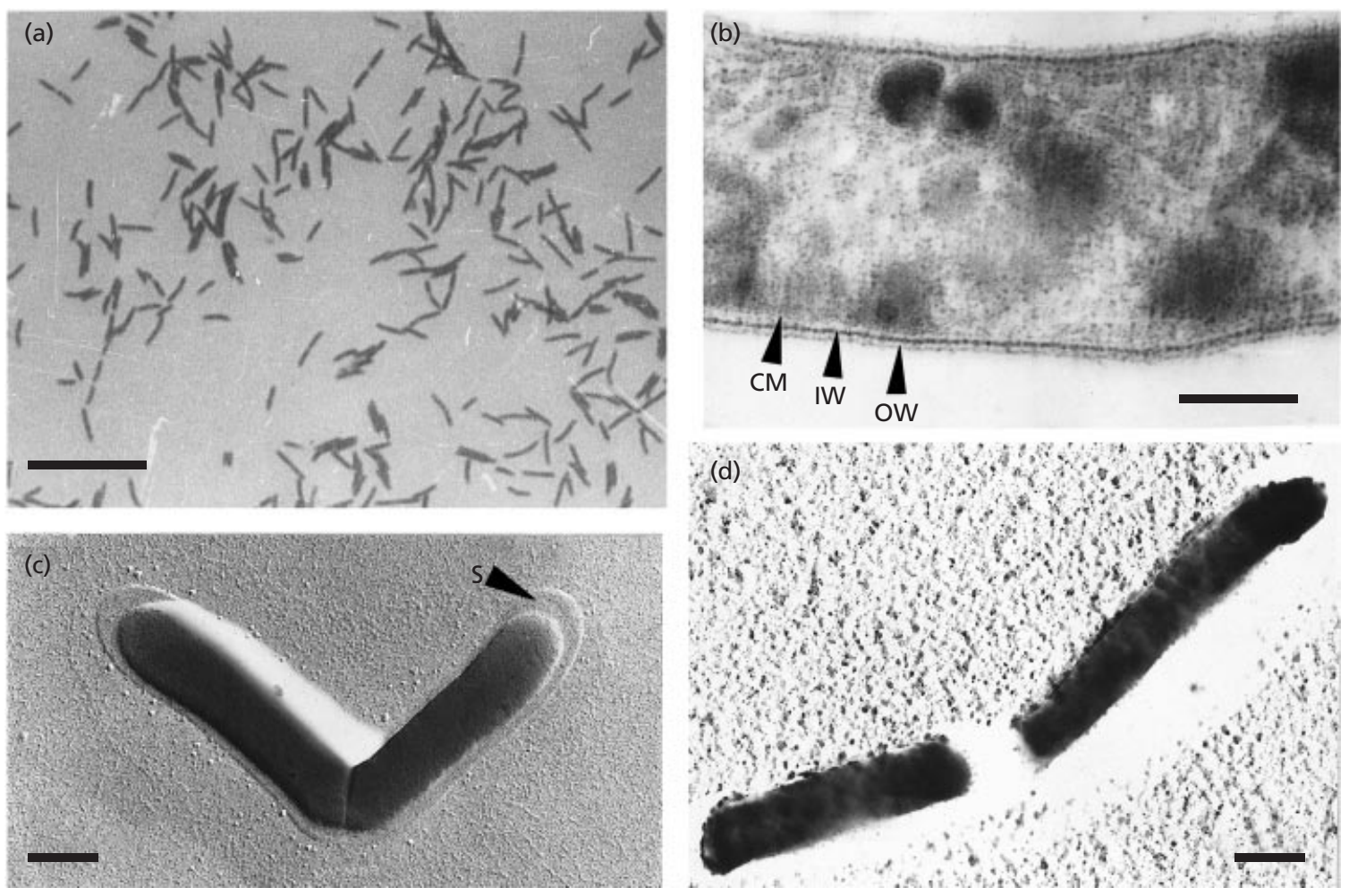

Fig. 1. Photomicrographs of strain $\mathrm{MB}^{\top}$. (a) Phase-contrast micrograph. Bar, $10 \mu \mathrm{m}$. (b) Electron micrograph of ultrathin section showing the cell wall structure. OW, less densely stained outer layer; IW, intensely stained inner layer; CM, cytoplasmic membrane. Bar, $0.2 \mu \mathrm{m}$. (c) Electron micrograph of platinum-shadowed cells grown on glucose-MB medium showing the outer sheathlike structure (S). Bar, $0.5 \mu \mathrm{m}$. (d) Electron micrograph of platinum-shadowed cells grown on starch-MB medium. Bar, $0.5 \mu \mathrm{m}$. 


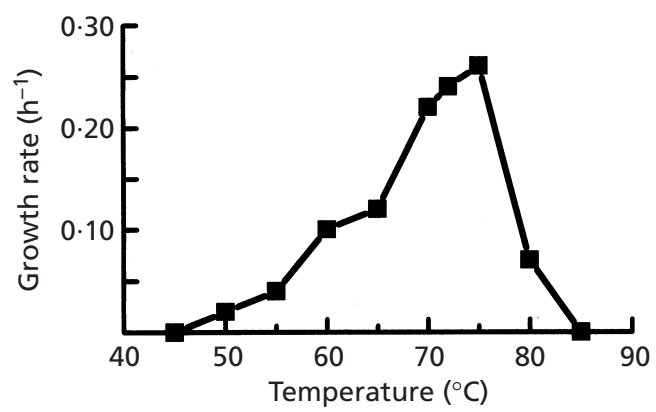

Fig. 2. Effect of temperature on the growth rate of strain MB4 ${ }^{\top}$.

resistance tests, indicating the absence of heat-resistant forms. Motility was not observed by phase-contrast microscopy and flagella were not observed in negatively stained electron microscopic preparations. The cell walls contained meso-diaminopimelic acid. A marginally wider outer sheathlike structure was present in cells grown on glucose. No such material was present in cells grown on starch.

\section{Physiological characteristics}

Strain MB4 ${ }^{\mathrm{T}}$ required yeast extract for growth and carbohydrate metabolism. Yeast extract could not be replaced with Casamino acids or Tryptone. In the absence of glucose but in the presence of yeast extract, little growth was obtained, indicating that yeast extract did not serve as a sole carbon and energy source. Strain MB4 ${ }^{T}$ grew well on starch, but could not degrade cellulose or xylan. Growth occurred on the following substrates: glucose, galactose, maltose, cellobiose, mannose, lactose, fructose and mannitol. No growth occurred on the following substrates: arabinose, sucrose, ribose, xylose, acetate, pyruvate, butyrate, lactate, citric acid, malic acid or glycerol. During glucose fermenation, $1.0 \mathrm{mmol}$ acetate, $0.7 \mathrm{mmol}$ ethanol, $1.5 \mathrm{mmol} \mathrm{CO}_{2}$ and $0.3 \mathrm{mmol} \mathrm{H}_{2}$ were produced per mmol glucose consumed. Propionate, isobutyrate and isovalerate were detected in trace amounts $(<0 \cdot 1 \mathrm{mM})$. No lactate was detected.

Strain $\mathrm{MB}^{\mathrm{T}}$ grew in reduced MB medium. In the presence of oxygen (indicated by the pink colour of the resazurin), strain $\mathrm{MB}^{\mathrm{T}}$ did not grow, suggesting that it was obligately anaerobic. When thiosulfate or sulfur was included in the medium, the growth of strain MB4 ${ }^{T}$ increased, with an increase in sulfide production. Sulfate or nitrate were not used as electron acceptors and did not affect the growth of strain $\mathrm{MB}^{\mathrm{T}}$. Sulfite and $\mathrm{H}_{2}$ inhibited growth of strain $\mathrm{MB} 4^{\mathrm{T}}$, and $\mathrm{H}_{2}$ inhibition could not be eliminated by addition of sulfur or thiosulfate to the culture.

Growth of strain MB4 ${ }^{\mathrm{T}}$ occurred at initial $\mathrm{pH}$ values ranging from $5 \cdot 5$ to $9 \cdot 0$, with an optimum of $7 \cdot 0-7 \cdot 5$ at $75^{\circ} \mathrm{C}$. Growth occurred in the medium containing $0-2.5 \% \mathrm{NaCl}$, with an optimum of $0.2 \%$ at $\mathrm{pH} 7.5$ and $75^{\circ} \mathrm{C}$. The temperature range for growth was 50 $80^{\circ} \mathrm{C}$, with an optimum of around $75^{\circ} \mathrm{C}$ at $\mathrm{pH} 7.5$ (Fig. 2). Under optimal conditions, the shortest doubling time was approximately $65 \mathrm{~min}$. At the end of optimal growth, the $\mathrm{pH}$ had decreased by $1.5-2.0$ units.

Growth of strain $\mathrm{MB} 4^{\mathrm{T}}$ was completely inhibited by $100 \mu \mathrm{g} \mathrm{ml}^{-1}$ chloromycetin, polymyxin $\mathrm{B}$, streptomycin sulfate or tetracycline. $\mathrm{HCl}$. Ampicillin or penicillin did not inhibit growth at the same concentration.

\section{DNA base composition}

The $\mathrm{G}+\mathrm{C}$ content of the DNA of strain MB4 ${ }^{\mathrm{T}}$ determined by the thermal denaturation temperature was $33 \pm 0 \cdot 2 \mathrm{~mol} \%$.

\section{S rDNA sequence analysis}

A 1512 bp sequence of $16 \mathrm{~S}$ rDNA from strain MB4 ${ }^{\mathrm{T}}$ was determined and compared with the members of the genus Thermoanaerobacter and related organisms. Positions of sequence alignment uncertainty were omitted from the analysis, and 1420 unambiguous nucleotides were used for computing evolutionary distance. The resulting phylogenetic tree (Fig. 3) showed strain $\mathrm{MB}^{\mathrm{T}}$ to be in the cluster comprising members of the genus Thermoanaerobacter and to constitute a monophyletic unit in the genus Thermoanaerobacter. The $16 \mathrm{~S}$ rDNA sequence of strain MB4 ${ }^{\mathrm{T}}$ exhibited levels of similarity ranging from 92.4 to $93.7 \%$ with the sequences of the bacteria currently assigned to the genus Thermoanaerobacter (Table 1). The highest level of sequence similarity $(93.7 \%)$ was with Thermoanaerobacter brockii subsp. brockii (Zeikus et al., 1979).

\section{DISCUSSION}

The genus Thermoanaerobacter was first introduced by Wiegel \& Ljungdahl (1981) and 14 species are currently recognized as valid: Thermoanaerobacter acetoethylicus (Ben-Bassat \& Zeikus, 1981), Thermoanaerobacter brockii subsp. brockii (Zeikus et al., 1979), Thermoanaerobacter brockii subsp. finnii (Schmid et al., 1986), Thermoanaerobacter brockii subsp. lactiethylicus (Cayol et al., 1995), Thermoanaerobacter ethanolicus (Weigel \& Ljungdahl, 1981), Thermoanaerobacter kivui (Leigh \& Wolfe, 1983), Thermoanaerobacter mathranii (Larsen et al., 1997), Thermoanaerobacter thermohydrosulfuricus (Lee et al., 1993), Thermoanaerobacter thermocopriae (Jin et al., 1988), Thermoanaerobacter wiegelii (Cook et al., 1996), Thermoanaerobacter italicus (Kozianowski et al., 1997), Thermoanaerobacter siderophilus (Slobodkin et al., 1999), Thermoanaerobacter subterraneus (Fardeau et al., 2000) and Thermoanaerobacter sulfurophilus (Bonch-Osmolovskaya et al., 1997).

The new isolate $\mathrm{MB} 4^{\mathrm{T}}$ shares some phenotypic characteristics with members of the genus Thermo- 


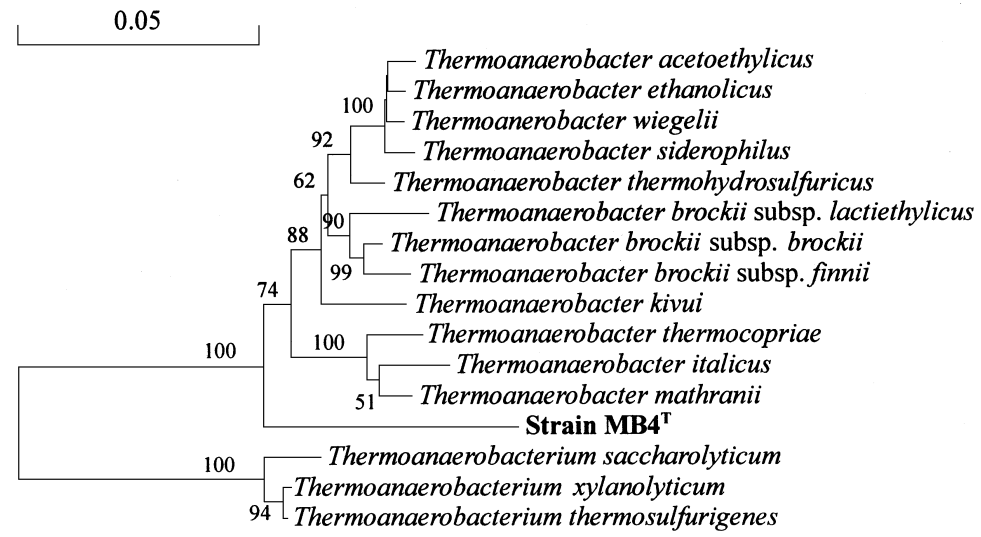

Fig. 3. Phylogenetic tree showing the position of strain $\mathrm{MB} 4^{\top}$ within the genus Thermoanaerobacter and related taxa based on 165 rDNA sequence similarity values. The numbers at the nodes of branches are the confidence values (expressed as percentages) obtained from 100 replications. Only values above $50 \%$ are indicated. Bar represents 5 base substitutions per 100 nucleotides.

Table 1. Distinguishing properties among strain $\mathrm{MB}^{\top}$ and other members of the genus Thermoanaerobacter

1, Strain MB4 ${ }^{\mathrm{T}} ; 2$, Thermoanaerobacter brockii subsp. brockii; 3, Thermoanaerobacter ethanolicus; 4, Thermoanaerobacter acetoethylicus; 5, Thermoanaerobacter kivui; 6, Thermoanaerobacter thermohydrosulfuricus; 7, Thermoanaerobacter wiegelii; 8, Thermoanaerobacter italicus; 9, Thermoanaerobacter thermocopriae; 10, Thermoanaerobacter siderophilus; 11, Thermoanaerobacter mathranii.

\begin{tabular}{|c|c|c|c|c|c|c|c|c|c|c|c|}
\hline Feature & 1 & 2 & 3 & 4 & 5 & 6 & 7 & 8 & 9 & 10 & 11 \\
\hline Gram reaction & - & + & $\mathrm{V}$ & - & - & $\mathrm{V}$ & - & - & - & + & $\mathrm{V}$ \\
\hline Spores & - & + & - & - & - & + & + & + & + & + & + \\
\hline Cell wall peptidoglycan diamino acid & $m$-DAP & NR & $m$-DAP & NR & NR & $m$-DAP & NR & $m$-DAP & NR & NR & NR \\
\hline Motility & - & + & + & + & - & + & + & - & + & + & + \\
\hline Optimum temperature $\left({ }^{\circ} \mathrm{C}\right)$ & 75 & 68 & 69 & 65 & 66 & 68 & 66 & 70 & 60 & 70 & 70 \\
\hline DNA G $+\mathrm{C}$ content $(\mathrm{mol} \%)$ & 33 & 31 & 32 & 31 & 38 & 37 & 35 & 34 & 37 & 32 & 37 \\
\hline $\mathrm{H}_{2}$ inhibition & + & NR & NR & - & - & + & NR & NR & NR & - & + \\
\hline Starch hydrolysis & + & + & + & + & - & + & + & + & $+\mathrm{W}$ & + & NR \\
\hline Xylan degradation & - & + & + & - & - & NR & NR & + & $+\mathrm{w}$ & - & + \\
\hline \multicolumn{12}{|l|}{ Growth substrates: } \\
\hline Glucose & + & + & + & + & + & + & + & + & + & + & + \\
\hline Sucrose & - & + & + & + & - & + & + & + & - & + & + \\
\hline Ribose & - & - & + & NR & - & + & - & NR & - & NR & + \\
\hline Xylose & - & - & + & - & NR & + & + & + & - & + & + \\
\hline Arabiose & - & + & - & NR & NR & $+\mathrm{w}$ & - & + & NR & - & + \\
\hline Mannitol & + & - & - & NR & - & $\mathrm{V}$ & + & NR & + & NR & + \\
\hline Glycerol & - & NR & - & NR & - & - & + & NR & - & + & - \\
\hline Pyruvate & - & + & + & - & + & + & - & NR & NR & + & NR \\
\hline \multicolumn{12}{|l|}{ Fermentation products: } \\
\hline Acetate & + & + & + & + & + & + & + & + & + & - & + \\
\hline Lactate & - & + & + & - & - & + & + & + & + & + & + \\
\hline Ethanol & $+\mathrm{w}$ & + & + & + & - & + & + & + & + & + & + \\
\hline \multicolumn{12}{|l|}{ Antibiotic inhibition: } \\
\hline Chloromycetin & + & + & + & - & NR & NR & - & NR & NR & + & + \\
\hline Penicillin & - & + & - & + & NR & + & - & NR & NR & - & + \\
\hline Streptomycin & + & + & - & + & NR & NR & - & NR & NR & - & NR \\
\hline Tetracycline & + & + & - & + & NR & NR & + & NR & NR & NR & + \\
\hline $\begin{array}{l}\text { 16s rDNA sequence similarity with } \\
\text { MB4 }^{\mathrm{T}}(\%)\end{array}$ & & $93 \cdot 7$ & $92 \cdot 7$ & $92 \cdot 9$ & $92 \cdot 6$ & $93 \cdot 2$ & $93 \cdot 1$ & $92 \cdot 4$ & $92 \cdot 5$ & $93 \cdot 0$ & $92 \cdot 6$ \\
\hline
\end{tabular}

*NR, Not reported; v, variable; +, positive; -, negative; +w, weak.

anaerobacter, i.e. obligately anaerobic rods, growth above $70{ }^{\circ} \mathrm{C}$, reduction of thiosulfate and sulfur to hydrogen sulfide, fermentation of glucose to acetate and ethanol and a DNA G + C content of $33 \mathrm{~mol} \%$. In these respects, strain $\mathrm{MB} 4^{\mathrm{T}}$ may be considered to be related to the genus Thermoanaerobacter. 
However, strain MB4 ${ }^{\mathrm{T}}$ is unlike the currently accepted species of Thermoanaerobacter in several important phenotypic properties, such as absence of spore production, Gram-staining reaction, motility, lactate production, xylan utilization, growth on some substrates and antibiotic susceptibility (Table 1). Furthermore, the optimum temperature for growth of strain MB4 ${ }^{\mathrm{T}}$ $\left(75^{\circ} \mathrm{C}\right)$ is the highest among species of the genus Thermoanaerobacter. These data suggest that strain $M B 4^{T}$ can be clearly differentiated from the validly described Thermoanaerobacter species.

The proposed relationship between strain $\mathrm{MB} 4^{\mathrm{T}}$ and the other species of the genus Thermoanaerobacter is also supported by the phylogenetic analysis. As shown previously, the genus Thermoanaerobacter forms a distinct phylogenetic cluster (Rainey et al., 1993; Collins et al., 1994). The results of our 16S rDNA sequence analysis indicated that strain $\mathrm{MB} 4^{\mathrm{T}}$ is clearly related to Thermoanaerobacter brockii subsp. brockii (level of similarity, 93.7\%) and falls into the Thermoanaerobacter cluster (Fig. 3). Moreover strain MB4 ${ }^{\mathrm{T}}$ represents a distinct branch within the Thermoanaerobacter cluster. The levels of $16 \mathrm{~S}$ rDNA similarity between strain $\mathrm{MB} 4^{\mathrm{T}}$ and other Thermoanaerobacter spp. range from 92.4 to $93.7 \%$, which is lower than that between species previously assigned to the genus Thermoanaerobacter on the basis of DNA-DNA homology values (Lee et al., 1993; Cayol et al., 1995). Stackebrandt \& Goebel (1994) demonstrated that strains belonging to the same genus that exhibit less than $97 \%$ 16S rDNA sequence similarity should be considered members of different species. The level of $16 \mathrm{~S}$ rDNA sequence similarity of $93.7 \%$ is low enough to designate strain $\mathrm{MB}^{\mathrm{T}}$ as a new species.

On the basis of the results described above, we propose strain $\mathrm{MB}^{\mathrm{T}}$ as a new species of the genus Thermoanaerobacter, namely Thermoanaerobacter tengcongensis. The type strain is $\mathrm{MB} 4^{\mathrm{T}}$, which has been deposited in the Chinese Collection of Microorganisms as strain AS $1.2430^{\mathrm{T}}$.

\section{Description of Thermoanaerobacter tengcongensis sp. nov}

Thermoanaerobacter tengcongensis (teng.con.gen'sis. N.L. masc. adj. tengcongensis pertaining to Tengcong, China).

Cells are Gram-negative rods, $0 \cdot 5-0.6 \mu \mathrm{m}$ in diameter and $1-10 \mu \mathrm{m}$ in length, occurring singly, in pairs or in chains. No spores are observed. Strictly anaerobic and thermophilic. Growth occurs at temperatures between 50 and $80{ }^{\circ} \mathrm{C}$, with an optimum of around $75^{\circ} \mathrm{C}$; at pH values between 5.5 and 9.0 , with an optimum of $7 \cdot 0-7 \cdot 5$; and at salinities between 0 and $2.5 \% \mathrm{NaCl}$, with an optimum of around $0.2 \% \mathrm{NaCl}$. Optimal doubling time is about $65 \mathrm{~min}$. Heterotrophic growth requires yeast extract, which cannot be replaced by Tryptone or Casamino acids. Utilizes glucose, galactose, maltose, cellobiose, mannose, fructose, lactose, mannitol and starch, but not arabinose, sucrose, ribose, xylose, cellulose, alginate, xylan, acetate, pyruvate, butyrate, lactate, citrate, malate or glycerol. The major fermentation end product on glucose is acetate. Hydrogen and sulfite inhibit growth. Thiosulfate and sulfur stimulate growth. Chloromycetin, polymyxin B, streptomycin sulfate and tetracycline. $\mathrm{HCl}$ inhibit growth. The genomic DNA has a $\mathrm{G}+\mathrm{C}$ content of $33 \mathrm{~mol} \%$. The isolate was obtained from a hot spring in Tengcong, China. The type strain is $\mathrm{MB}^{\mathrm{T}}$ ( = Chinese Collection of Microorganisms AS $\left.1.2430^{\mathrm{T}}=\mathrm{JCM} 11007^{\mathrm{T}}\right)$.

\section{ACKNOWLEDGEMENTS}

We thank Dr A. Slobodkin and Professor E. A. BonchOsmolovskaya for kindly providing the Themoanaerobacter reference strains. We thank Professor Trüper for suggestions for the etymology. We also thank Dr Cowan for helpful corrections for improvement of the manuscript.

\section{REFERENCES}

Altschul, S. F., Madden, T. L., Schaffer, A. A., Zhang, J., Zhang, Z., Miller, W. \& Lipman, D. J. (1997). Gapped BLAST and PSI-BLAST: a new generation of protein database search programs. Nucleic Acids Res 25, 3389-3402.

Balch, W. E., Fox, G. E., Magrum, R. J. \& Wolfe, R. S. (1979). Methanogens: reevaluation of a unique biological group. Microbiol Rev 43, 260-296.

Ben-Bassat, A. \& Zeikus, J. G. (1981). Thermobacteroides acetoethylicus gen. nov. and sp. nov., a new chemoorganotrophic, anaerobic, thermophilic bacterium. Arch Microbiol 128, 365-370.

Bonch-Osmolovskaya, E. A., Miroshnichenko, M. L., Chernykh, N. A., Kostrikina, N. A., Pikuta, E. V. \& Rainey, F. A. (1997). Reduction of elemental sulfur by moderately thermophilic organotrophic bacteria and the description of Thermoanaerobacter sulfurophilus sp. nov. Microbiology (English translation of Mikrobiologiya) 66, 483-489.

Brock, T. D. (1986). Introduction: an overview of the thermophiles. In Thermophiles: General, Molecular, and Applied Microbiology, pp. 1-16. Edited by T. D. Brock. New York: Wiley.

Brosius, J., Palmer, J. L., Kennedy, J. P. \& Noller, H. F. (1978). Complete nucleotide sequence of a 16S ribosomal RNA gene from Escherichia coli. Proc Natl Acad Sci U S A 75, 4801-4805.

Buck, J. D. (1982). Nonstaining (KOH) method for determination of Gram reactions of marine bacteria. Appl Environ Microbiol 44, 992-993.

Cayol, J.-L., Ollivier, B., Patel, B. K. C., Ravot, G., Magot, M., Ageron, E., Grimont, P. A. D. \& Garcia, J.-L. (1995). Description of Thermoanaerobacter brockii subsp. lactiethylicus subsp. nov., isolated from a deep subsurface French oil well, a proposal to reclassify Thermoanaerobacter finnii as Thermoanaerobacter brockii subsp. finnii comb. nov., and an emended description of Thermoanaerobacter brockii. Int J Syst Bacteriol 45, 783-789.

Collins, M. D., Lawson, P. A., Willems, A., Cordoba, J. J., Fernandez-Garayzabal, J., Garcia, P., Cai, J., Hippe, H. \& Farrow, J. A. E. (1994). The phylogeny of the genus Clostridium: proposal of five new genera and eleven new species combinations. Int $J$ Syst Bacteriol 44, 812-826. 
Cook, G. M., Rainey, F. A., Patel, B. K. C. \& Morgan, H. W. (1996). Characterization of a new obligately anaerobic thermophile, Thermoanaerobacter wiegelii sp. nov. Int J Syst Bacteriol 46, 123-127.

Doetsch, R. N. (1981). Determinative methods of light microscopy. In Mannual of Methods for General Bacteriology, pp. 21-33. Edited by P. Gerhardt, R. G. E. Murray, R. N. Costilow, E. W. Nester, W. A. Wood, N. R. Krieg \& G. B. Philips. Washington, DC: American Society for Microbiology.

Fardeau, M.-L., Ollivier, B., Patel, B. K. C., Magot, M., Thomas, P., Rimbault, A., Rocchiccioli, F. \& Garcia, J.-L. (1997). Thermotoga hypogea sp. nov., a xylanolytic, thermophilic bacterium from an oil-producing well. Int J Syst Bacteriol 47, 1013-1019.

Fardeau, M.-L., Magot, M., Patel, B. K. C., Thomas, P., Garcoia, J.-L. \& Ollivier, B. (2000). Thermoanaerobacter subterraneus $\mathrm{sp}$. nov., a novel thermophile isolated from oilfield water. Int $J$ Syst Evol Microbiol 50, 2141-2149.

Hungate, R. E. (1969). A roll tube method for cultivation of strict anaerobes. Methods Microbiol 3B, 117-132.

Jin, F., Yamasato, K. \& Toda, K. (1988). Clostridium thermocopriae sp. nov., a cellulolytic thermophile from animal feces, compost, soil, and a hot spring in Japan. Int J Syst Bacteriol 38, 279-281.

Kozianowski, G., Canganella, F., Rainey, F. A., Hippe, H. \& Antranikian, G. (1997). Purification and characterization of thermostable pectate-lyases from a newly isolated thermophilic bacterium, Thermoanaerobacter italicus sp. nov. Extremophiles 1, 175-182.

Kristjansson, J. K. \& Stetter, K. O. (1992). Thermophilic bacteria. In Thermophilic Bacteria, pp. 1-13. Edited by J. K. Kristjansson. London: CRC Press.

Larsen, L., Nielsen, P. \& Ahring, B. K. (1997). Thermoanaerobacter mathranii sp. nov., an ethanol-producing, extremely thermophilic anaerobic bacterium from a hot spring in Iceland. Arch Microbiol 168, 114-119.

Lee, Y.-E., Jain, M. K., Lee, C., Lowe, S. E. \& Zeikus, J. G. (1993). Taxonomic distinction of saccharolytic thermophilic anaerobes: description of Thermoanaerobacterium xylanolyticum gen. nov., sp. nov., and Thermoanaerobacterium saccharolyticum gen. nov., sp. nov.; reclassification of Thermoanaerobium brockii, Clostridium thermosulfurogenes, and Clostridium thermohydrosulfuricum E100-69 as Thermoanaerobacter brockii comb. nov., Thermoanaerobacterium thermosulfurigenes comb. nov., and Thermoanaerobacter thermohydrosulfuricus comb. nov., respectively; and transfer of Clostridium thermohydrosulfuricum $39 \mathrm{E}$ to Thermoanaerobacter ethanolicus. Int J Syst Bacteriol 43, 41-51.

Leigh, J. A. \& Wolfe, R. S. (1983). Acetogenium kivui, a new thermophilic hydrogen-oxidizing, acetogenic bacterium. Arch Microbiol 129, 275-280.

Marmur, J. (1961). A procedure for the isolation of deoxyribonucleic acid from microorganisms. J Mol Biol 3, 208-218.
Marmur, J. \& Doty, P. (1962). Determination of the base composition of deoxyribonucleic acid from its thermal denaturation temperature. J Mol Biol 5, 109-118.

Patel, B. K. C., Morgan, H. W. \& Daniel, R. M. (1985). Fervidobacterium nodosum gen. nov. and spec. nov., a new chemoorganotrophic, caldoactive, anaerobic bacterium. Arch Microbiol 141, 63-69.

Rainey, F. A., Ward, A. L., Morgan, H. W., Toalster, R. \& Brandt, E. S. (1993). Phylogenetic analysis of anaerobic thermophilic bacteria: aids for their reclassification. $J$ Bacteriol 175, 4772-4779.

Saitou, N. \& Nei, M. (1987). The neighbor-joining method: a new method for reconstructing phylogenetic trees. Mol Biol Evol 4, 406-425.

Sanger, F., Nicklen, S. \& Coulson, A. R. (1977). DNA sequencing with chain-terminating inhibitors. Proc Natl Acad Sci US A 74, 5463-5467.

Schleifer, K. H. (1985). Analysis of the chemical composition and primary structure of murein. Methods Microbiol 18, 123-156.

Schmid, U., Giesel, H., Schoberth, S. M. \& Sahm, H. (1986). Thermoanaerobacter finnii spec. nov., a new ethanologenic sporogenous bacterium. Syst Appl Microbiol 8, 80-85.

Slobodkin, A. I., Tourova, T. P., Kuznetsov, B. B., Kostrikina, N. A., Chernyh, N. A. \& Bonch-Osmolovskaya, E. A. (1999). Thermoanaerobacter siderophilus sp. nov., a novel dissimilatory $\mathrm{Fe}(\mathrm{III})$-reducing, anaerobic, thermophilic bacterium. Int J Syst Bacteriol 49, 1471-1478.

Stackebrandt, E. \& Goebel, B. M. (1994). Taxonomic note: a place for DNA-DNA reassociation and 16S rRNA sequence analysis in the present species definition in bacteriology. Int $J$ Syst Bacteriol 44, 846-849.

Thompson, J. D., Higgins, D. G. \& Gibson, T. J. (1994). CLUSTAL $\mathrm{W}$ : improving the sensitivity of progressive multiple sequence alignments through sequence weighting, position-specific gap penalties and weight matrix choice. Nucleic Acids Res 22, 4673-4680.

Van de Peer, Y. \& De Wachter, R. (1994). TREECON for Windows: a software package for the construction and drawing of evolutionary trees for the Microsoft Windows environment. Comput Appl Biosci 10, 569-570.

Wiegel, J. \& Ljungdahl, L. G. (1981). Thermoanaerobacter ethanolicus gen. nov. and sp. nov., a new extreme thermophilic, anaerobic bacterium. Arch Microbiol 128, 343-348.

Wiegel, J., Mothershed, C. P. \& Puls, J. (1985). Differences in xylan degradation by various noncellulolytic thermophilic anaerobes and Clostridium thermocellum. Appl Environ Microbiol 49, 656-659.

Zeikus, J. G., Hegge, P. W. \& Anderson, M. A. (1979). Thermoanaerobium brockii gen. nov. and sp. nov., a new chemoorganotrophic, caldoactive, anaerobic bacterium. Arch Microbiol 122, 41-48. 